American Journal of Agricultural and Biological Sciences 9 (3): 294-298, 2014

ISSN: $1557-4989$

(C) 2014 W.B. Gordon et al., This open access article is distributed under a Creative Commons Attribution

(CC-BY) 3.0 license

doi:10.3844/ajabssp.2014.294.298 Published Online 9 (3) 2014 (http://www.thescipub.com/ajabs.toc)

\title{
IMPROVING PHOSPHORUS NUTRITION OF CORN
}

\author{
${ }^{1}$ Walter B. Gordon, ${ }^{2}$ Larry Murphy and ${ }^{3}$ Pawel Wiatrak \\ ${ }^{1}$ Department of Agronomy, Kansas State University, Manhattan, Kansas, USA \\ ${ }^{2}$ Murphy Agro, Manhattan, Kansas, USA \\ ${ }^{3}$ School of Agricultural, Forest and Environmental Sciences, Clemson University, Edisto REC, Blackville, USA
}

Received 2014-03-10; Revised 2014-03-15; Accepted 2014-03-18

\begin{abstract}
Phosphorus (P) generally occurs in soils as the anions $\mathrm{H}_{2} \mathrm{PO}_{4}{ }^{-}$or $\mathrm{HPO}_{4}{ }^{-2}$ depending on soil $\mathrm{pH}$. These anions readily react with soil cations such as calcium, magnesium, iron and aluminum to produce various phosphate compounds of very limited water solubility. Crop recovery of applied phosphate fertilizer can be quite low during the season of application. In addition, the large amounts of crop residue present in no-tillage production systems can lower soil temperature thus reducing root growth and nutrient uptake of plants even on soils not low in available Phosphorus (P). Specialty Fertilizer Products, Leawood, KS has developed and patented a product registered as AVAIL ${ }^{\circledR}$ that is reported to attract and sequester antagonistic cations out of the soil solution leaving more of the applied $\mathrm{P}$ in available form for plant uptake. The objective of this experiment was to evaluate the effectiveness of AVAIL treated P-fertilizer on growth, P-uptake and yield of irrigated corn (Zea mays L.) grown in a no-tillage production system. A 3-year experiment was conducted from 2001-2003 at the North Central Kansas Experiment Field, located near Scandia, KS, on a Crete silt loam soil (fine, montmorillonitic, mesic Pachic Arquistoll). Treatments consisted of three rates of $\mathrm{P}$ with or without AVAIL. A no $\mathrm{P}$ check plot was also included. When averaged over the years and P rates, the use of AVAIL increased yield of corn by $1.1 \mathrm{Mg} \mathrm{ha}^{-1}$. AVAIL also increased corn dry weight at the six-leaf stage, whole plant $\mathrm{P}$ uptake at the six-leaf stage and $\mathrm{P}$ concentration at mid-silk. The use of AVAIL proved beneficial in overcoming many of the problems associated with P nutrition in corn. AVAIL consistently increased P uptake and yield in this experiment.
\end{abstract}

Keywords: Corn, Avail, Corn, Phosphorus

\section{INTRODUCTION}

Phosphorus is one of the essential elements, even though it is less abundant in soils than nitrogen and potassium. Most of the phosphate that is used in fertilizers is derived from rock phosphate, which is a non-renewable resource. Some have predicted that global phosphate resources could be depleted within the next century (Cordell et al., 2009). This comes at a time when more $\mathrm{P}$ fertilizers are needed to produce food and fiber to sustain a growing global population (Gilbert, 2009). Proper P management is therefore needed to obtain the maximum benefit from a diminishing resource. $\mathrm{P}$ is involved in many vital plant growth processes. The most essential Corresponding Author: Walter B. Gordon, Department of Agronomy, Kansas State University, Manhattan, Kansas, USA function is in energy storage and transfer. Energy obtained from photosynthesis and metabolism of carbohydrates is stored in phosphate compounds for subsequent use in growth and reproductive processes. The total $\mathrm{P}$ in surface soils varies from 0.0005 to $0.15 \%$ (Havlin et al., 2005) and has little or no relationship to the availability of $\mathrm{P}$ to plants. In soils, $\mathrm{P}$ generally occurs as the as the anions $\mathrm{H}_{2} \mathrm{PO}_{4}^{-}$or $\mathrm{HPO}_{4}^{-2}$, depending on the soil $\mathrm{pH}$. These anions readily react with soil cations such as Calcium (Ca), Magnesium (Mg), Iron (Fe) and Aluminum (Al) to produce various phosphate compounds of very limited water solubility. This explains the relatively low plant uptake efficiency of applied $\mathrm{P}$ by the first crop following fertilizer 
application. Reactions of $\mathrm{P}$ in soils vary with soil $\mathrm{pH}$. Highly weathered, acid soils generally contain large amounts of soluble $\mathrm{Fe}$ and $\mathrm{Al}$ which react with soluble $\mathrm{P}$ compounds in the soil to form $\mathrm{Fe}$ and $\mathrm{Al}$ phosphates, whose solubility is rather low. When $\mathrm{P}$ has been incorporated into such compounds, it is said to be 'fixed' in terms of its subsequent availability to plants. Alkaline soils contain appreciable quantities of Ca compounds, especially calcium carbonate, which react with soluble $\mathrm{P}$ compounds to form various calcium phosphates. As with acid soils, reactions of soluble $\mathrm{P}$ with $\mathrm{Ca}$ in solution or that sorbed on soil colloids as well as precipitated as calcium carbonate can decrease the availability of applied P.

In order to overcome problems associated with $\mathrm{P}$ nutrition in crop, specialty fertilizer products, leawood, KS has developed and patented family of dicarboxylic copolymers that can be used as a coating on granular or mixed into liquid phosphate fertilizers The registered trade name of this product is AVAIL and it is identified as a partial sodium salt of maleicitaconic copolymer (CAS\#556055-76-6). The compound has a high charge density (cation exchange capacity of approximately 1,800 miliequivalents/100 g) that is reported to sequester multivalent cations such as calcium, magnesium, iron and aluminum that normally form insoluble precipitants with applied $\mathrm{P}$ fertilizer (Murphy and Sanders, 2007). The objective of this research was to evaluate the use of AVAIL with $\mathrm{P}$ fertilizer in order to improve nutrient management in a no-tillage corn production system.

\section{MATERIALS AND METHODS}

\subsection{Site Preparation and Management}

An irrigated corn experiment was conducted at the North Central Kansas Experiment Field, located near Scandia, KS, on a Crete silt loam soil, from the spring of 2001 to the fall of 2003. Analysis by the Kansas State University Soil Testing Laboratory showed that in the top $15 \mathrm{~cm}$ of soil, initial soil $\mathrm{pH}$ (April 2001) was 7.0; organic matter was $22 \mathrm{~g} \mathrm{~kg}^{-1}$; Bray-1 $\mathrm{P}$ was $30 \mathrm{mg} \mathrm{kg}^{-1}$; exchangeable $\mathrm{K}$ was $320 \mathrm{mg} \mathrm{kg}^{-1}$ and DTPA-extractable $\mathrm{Zn}$ was $1.8 \mathrm{mg} \mathrm{kg}^{-1}$. The experiment was rotated annually with an adjacent block that was uniformly fertilized. Previous crop was always corn. The experimental design was a randomized complete block with four replications. Plots consisted of four rows (76 cm inter-row spacing) $9.2 \mathrm{~m}$ long. Treatments consisted of applying $\mathrm{P}$ fertilizer as mono-ammonium phosphate (MAP, 11-
52-0) at rates to give 22, 44 or $66 \mathrm{~kg} \mathrm{ha}^{-1} \mathrm{P}_{2} \mathrm{O}_{5}$ either treated with $0.25 \%$ AVAIL or untreated. A no-P check plot was also included. The $\mathrm{P}$ fertilizer was banded beside the old rows 7-10 days before planting. Nitrogen $(\mathrm{N})$ was balanced on the treatments so that each plot received a total of $200 \mathrm{~kg} \mathrm{ha}^{-1} \mathrm{~N}$ regardless of the amount of MAP applied.

The corn hybrid Dekalb DKC60-19 was planted without tillage into corn stubble in late April each year of the three-year study at the rate of 74,400 seeds $\mathrm{ha}^{-1}$. Residue cover at planting was approximately $80 \%$ of the total soil area. Plant populations averaged 72,654; 72,865; and 72,922 plants $\mathrm{ha}^{-1}$ in 2001, 2002 and 2003, respectively and were not affected by treatment $(p<0.6018)$. Plant counts were taken from the center two rows of each plot at the V3 stage of growth. Harvest occurred in early October of each year. The center two rows of each four-row plot were mechanically harvested to determine grain yield. Grain yield was adjusted to constant $155 \mathrm{~g} \mathrm{~kg}^{-1}$ moisture. Irrigation water was applied when $50 \%$ of the plant available water in the top $80 \mathrm{~cm}$ of the soil profile was depleted. Irrigation water application totals were 12.6, 15.8 and $19.5 \mathrm{~cm}$ for 2001, 2002 and 2003, respectively.

\subsection{Plant Measurements}

Whole plant samples (10 randomly selected, above-ground plants were plot) were collected at the V6 stage for analysis of dry matter and P determinations. When $50 \%$ of the plants in the experimental area were in the mid-silk stage twentyfive randomly selected leaves (first leaf above the ear) were taken from each plot for elemental analysis. Plant samples were all taken from either the first or fourth row of each plot. After collection, samples were dried, ground, weighed and analyzed for $\mathrm{P}$ concentration. Plant analysis was conducted by Kansas State University's Soil Testing Laboratory.

\subsection{Statistical Analysis}

Data were analyzed using analysis of variance. Duncan's Multiple Range Test was employed to separate treatment means.

\section{RESULTS}

\subsection{Grain Yields}

Growing season rainfall was above normal for two of the three years of the experiment (Table 1). July rainfall 
was much below normal in both 2002 and 2003, but adequate irrigation water was available and yields did not suffer. Temperatures were near the thirty-year average for all three years of the experiment.

Although the experimental site was not low in available $\mathrm{P}$, a good response to $\mathrm{P}$ was seen each year of the experiment (Table 2). When averaged over years and $\mathrm{P}$ rates, plots receiving $\mathrm{P}$, with or without AVAIL, yielded $2.2 \mathrm{Mg} \mathrm{ha}^{-1}$ greater than the no-P check. At every level of applied $\mathrm{P}$, yields were greater in plots receiving $\mathrm{P}$ treated with AVAIL than in plots receiving untreated $P$. When averaged over years and $\mathrm{P}$ rates AVAIL increased grain yield by $1.1 \mathrm{Mg} \mathrm{ha}^{-1}$ over the $\mathrm{P}$ alone treatments. In general yields increased with increasing $\mathrm{P}$ rate.

\subsection{Early Season Dry-Matter Production and Nutrient Uptake}

All applied P treatments significantly increased V6 stage whole plant dry weight, regardless of AVAIL treatment as compared to the no-P check (Table 3). When averaged over years and $\mathrm{P}$ treatments dry weight was increased by $183 \mathrm{~kg} \mathrm{ha}^{-1}$ over the no P check. As with yield, V6 whole plant dry weight increased with increasing $\mathrm{P}$ rate in both the AVAIL treated and untreated MAP plots. The use of AVAIL increased dry weight in each year of the experiment. When averaged over years and $\mathrm{P}$ rates AVAIL increased whole plant dry weight by $16 \%$ over the no AVAIL P treatments. Corn V6 stage plant P uptake followed the same trends as dry weight (Table 4 and 5). P-uptake was significantly lower for the no-P check than for plots receiving applied $\mathrm{P}$ with or without AVAIL. The use of AVAIL resulted in better $P$ uptake at all rates of applied P. When averaged over P-rates and years AVAIL increased P uptake by over $12 \%$ as compared to untreated P. Early season P-uptake trends continued into mid-silk. The lowest $\mathrm{P}$ concentration was found in the no-P check and $\mathrm{P}$ concentration increased with increasing $\mathrm{P}$ rate. When averaged over $\mathrm{P}$ rates and years, the use of AVAIL increased $P$ concentration by nearly 5\%. The use of AVAIL consistently increased growth and $\mathrm{P}$ content of corn.

Table 1. Growing season weather data, Scandia, KS

\begin{tabular}{|c|c|c|c|c|c|c|c|c|}
\hline \multirow[b]{2}{*}{ Year } & \multicolumn{8}{|c|}{ Month } \\
\hline & Apr. & May & June & July & Aug. & Sep. & Oct. & Average/total \\
\hline \multicolumn{9}{|c|}{$\overline{\text { Temperature }\left({ }^{\circ} \mathbf{C}\right)}$} \\
\hline 2001 & 13.8 & 17.9 & 22.5 & 26.3 & 23.5 & 17.9 & 14.2 & 19.4 \\
\hline 2002 & 12.4 & 17.6 & 23.1 & 26.3 & 25.2 & 18.6 & 14.0 & 19.6 \\
\hline 2003 & 10.8 & 17.0 & 22.3 & 28.2 & 26.6 & 22.0 & 14.1 & 20.1 \\
\hline 30-yr avg. & 12.0 & 17.8 & 23.3 & 26.1 & 25.0 & 19.4 & 13.3 & 19.6 \\
\hline \multicolumn{9}{|c|}{ Precipitation (mm) } \\
\hline 2001 & 88.9 & 251.5 & 85.5 & 154.4 & 41.9 & 132.0 & 68.1 & 822.3 \\
\hline 2002 & 59.1 & 134.1 & 37.1 & 11.2 & 44.7 & 48.8 & 133.6 & 468.6 \\
\hline 2003 & 94.2 & 145.0 & 250.6 & 3.0 & 487.2 & 192.5 & 16.5 & 1189.0 \\
\hline $30-y r$ avg. & 72.9 & 110.5 & 111.0 & 100.8 & 93.4 & 82.6 & 60.2 & 631.4 \\
\hline
\end{tabular}

Table 2. Corn yield response to phosphorus fertilizer with and without AVAIL

\begin{tabular}{llllll}
\hline $\mathrm{P}_{2} \mathrm{O}_{5}$ rate & AVAIL & 2001 & 2002 & 2003 & 3 -year Avg. \\
\hline $\mathrm{Kg} \mathrm{ha}^{-1}$ & & & $\mathrm{Mg} \mathrm{ha}^{-1}$ & & \\
0 & No & $10.9 \mathrm{c}$ & $7.5 \mathrm{e}$ & $10.6 \mathrm{~d}$ & $10.7 \mathrm{e}$ \\
22 & No & $11.8 \mathrm{~b}$ & $8.9 \mathrm{~d}$ & $11.4 \mathrm{c}$ & $10.7 \mathrm{~d}$ \\
44 & No & $12.0 \mathrm{~b}$ & $10.6 \mathrm{c}$ & $11.8 \mathrm{bc}$ & $11.9 \mathrm{bc}$ \\
66 & No & $11.9 \mathrm{~b}$ & $10.9 \mathrm{bc}$ & $12.2 \mathrm{~b}$ & $12.1 \mathrm{abc}$ \\
22 & Yes & $12.1 \mathrm{~b}$ & $10.9 \mathrm{bc}$ & $13.2 \mathrm{a}$ & $12.4 \mathrm{ab}$ \\
44 & Yes & $12.2 \mathrm{~b}$ & $11.9 \mathrm{ab}$ & $13.1 \mathrm{a}$ & $12.8 \mathrm{a}$ \\
66 & Yes & $13.1 \mathrm{a}$ & $12.1 \mathrm{a}$ & $13.2 \mathrm{a}$ & 0.8 \\
$\mathrm{LSD}$ & & 0.6 & 1.0 & 0.6 & 5.8 \\
$\mathrm{CV} \%$ & & 3.9 & 8.9 & 4.2 & \\
\hline
\end{tabular}


Walter B. Gordon et al. / American Journal of Agricultural and Biological Sciences 9 (3): 294-298, 2014

Table 3. Corn V6 whole plant dry weight as affected by $\mathrm{P}$ fertilizer with and without AVAIL

\begin{tabular}{|c|c|c|c|c|c|}
\hline $\mathrm{P}_{2} \mathrm{O}_{5}$ rate & AVAIL & 2001 & 2002 & 2003 & 3-year Avg. \\
\hline $\mathrm{kg} \mathrm{ha}^{-1}$ & & & $\mathrm{~kg} \mathrm{ha}^{-1}$ & & \\
\hline 0 & No & $522.3 \mathrm{e}$ & $250.8 \mathrm{c}$ & $315.3 \mathrm{e}$ & $362.8 \mathrm{f}$ \\
\hline 22 & No & $606.2 d$ & $368.9 b$ & $381.6 \mathrm{~d}$ & $454.9 \mathrm{e}$ \\
\hline 44 & No & $680.1 \mathrm{~cd}$ & $382.6 \mathrm{~b}$ & $453.1 \mathrm{c}$ & $460.2 \mathrm{de}$ \\
\hline 66 & No & $829.1 \mathrm{~b}$ & $433.7 \mathrm{a}$ & $471.2 \mathrm{~b}$ & $577.9 \mathrm{bc}$ \\
\hline 22 & Yes & $727.2 \mathrm{c}$ & $432.1 \mathrm{a}$ & $437.6 \mathrm{c}$ & $532.3 \mathrm{~cd}$ \\
\hline 44 & Yes & $897.3 b$ & $432.7 \mathrm{a}$ & $478.7 \mathrm{~b}$ & $602.7 \mathrm{ab}$ \\
\hline 66 & Yes & $983.2 \mathrm{a}$ & $432.7 \mathrm{a}$ & $518.8 \mathrm{a}$ & $644.9 \mathrm{a}$ \\
\hline $\operatorname{LSD}_{(0.05)}$ & & 79.6 & 37.6 & 17.2 & 50.4 \\
\hline $\mathrm{CV} \%$ & & 9.0 & 8.2 & 3.3 & 8.4 \\
\hline
\end{tabular}

Table 4. Corn V6 whole plant $\mathrm{P}$ as affected by $\mathrm{P}$ fertilizer rate with and without AVAIL

\begin{tabular}{llllll}
\hline $\mathrm{P}_{2} \mathrm{O}_{5}$ rate & AVAIL & 2001 & 2002 & 2003 & 3 -year Avg. \\
\hline $\mathrm{Kg} \mathrm{ha}^{-1}$ & & & $\mathrm{Kg} \mathrm{ha}^{-1}$ & $1.12 \mathrm{f}$ & $1.19 \mathrm{e}$ \\
0 & No & $1.40 \mathrm{~d}$ & $1.07 \mathrm{e}$ & $2.39 \mathrm{e}$ & $2.07 \mathrm{~d}$ \\
22 & No & $1.96 \mathrm{c}$ & $1.87 \mathrm{bc}$ & $2.46 \mathrm{~cd}$ & $2.23 \mathrm{~cd}$ \\
44 & No & $2.19 \mathrm{c}$ & $2.06 \mathrm{~b}$ & $2.52 \mathrm{bc}$ & $2.50 \mathrm{~b}$ \\
66 & No & $2.72 \mathrm{~b}$ & $2.22 \mathrm{a}$ & $2.41 \mathrm{de}$ & $2.43 \mathrm{bc}$ \\
22 & Yes & $2.67 \mathrm{~b}$ & $2.20 \mathrm{~d}$ & $2.55 \mathrm{~b}$ & $2.52 \mathrm{~b}$ \\
44 & Yes & $2.75 \mathrm{~b}$ & $2.27 \mathrm{~cd}$ & $2.66 \mathrm{a}$ & $2.80 \mathrm{a}$ \\
66 & Yes & $3.43 \mathrm{a}$ & $2.31 \mathrm{bc}$ & 0.06 & 0.24 \\
$\mathrm{LSD}_{(0.05)}$ & & 0.36 & 0.22 & 3.1 & 9.5 \\
$\mathrm{CV}$ & & 12.6 & 10.2 & & \\
\hline
\end{tabular}

Table 5. Corn ear leaf $\mathrm{P}$ concentration as affected by $\mathrm{P}$ fertilizer rate with and without AVAIL

\begin{tabular}{llllll}
\hline $\mathrm{P}_{2} \mathrm{O}_{5}$ rate & AVAIL & 2001 & 2002 & 2003 & $3-$ year Avg. \\
\hline $\mathrm{kg} \mathrm{ha}^{-1}$ & & & $\mathrm{~g} \mathrm{~kg}^{-1}$ & $2.04 \mathrm{e}$ & $2.05 \mathrm{e}$ \\
0 & No & $1.99 \mathrm{e}$ & $2.12 \mathrm{f}$ & $2.38 \mathrm{~d}$ & $2.32 \mathrm{~d}$ \\
22 & No & $2.29 \mathrm{~d}$ & $2.29 \mathrm{e}$ & $2.48 \mathrm{c}$ & $2.45 \mathrm{c}$ \\
44 & No & $2.39 \mathrm{c}$ & $2.47 \mathrm{~cd}$ & $2.55 \mathrm{~b}$ & $2.54 \mathrm{~b}$ \\
66 & No & $2.51 \mathrm{~b}$ & $2.57 \mathrm{~b}$ & $2.44 \mathrm{c}$ & $2.40 \mathrm{c}$ \\
22 & Yes & $2.36 \mathrm{c}$ & $2.40 \mathrm{~d}$ & $2.58 \mathrm{~b}$ & $2.56 \mathrm{~b}$ \\
44 & Yes & $2.57 \mathrm{a}$ & $2.53 \mathrm{bc}$ & $2.65 \mathrm{a}$ & $2.67 \mathrm{a}$ \\
66 & Yes & $2.61 \mathrm{a}$ & $2.74 \mathrm{a}$ & 0.06 & 0.06 \\
LSD & & 0.05 & 0.07 & 2.2 & 2.2 \\
$\mathrm{CV} \%$ & & 1.9 & 2.4 & & 2 \\
\hline
\end{tabular}

\section{DISCUSSION}

Often experiments show that only $5-25 \%$ of applied phosphate is taken up by a single crop (Cooke, 1981). In long-term experiments at the Rothamsted Experiment Station, UK, Widdowson and Penny (1973) found that no crop recovered more than $22 \%$ of applied $\mathrm{P}$ in a given year. In some mineral soils, the $\mathrm{P}$ concentration in the soil solution and $\mathrm{P}$ mobility can be enhanced by complexation of $\mathrm{Fe}$ and $\mathrm{Al}$ sesquioxides with organic ligands, because this process reduces the number of potential binding sites. Organic ligands may further increase $\mathrm{P}$ availability by anion exchange, replacing $\mathrm{P}$ from the binding sites (Gerke, 1992; 1993). Soil temperature can also affect the availability of $\mathrm{P}$ to plants. When planting early in high residue conditions, there is a greater risk of cool soil temperatures reducing root growth and nutrient uptake. Lower than optimum soil temperature can greatly affect root growth rate (Ching and Barber, 1979) and P uptake by roots (Mackay and Barber, 1984).

\section{CONCLUSION}

This study investigated the use of AVAIL with $\mathrm{P}$ fertilizer in order to improve nutrient management in a no-tillage corn production system. Influencing or controlling reactions in the environment around the fertilizer granule has shown to have significant benefits 
to the fate of applied nutrients and subsequent plant response to applied $\mathrm{P}$ fertilizer. The objective of agricultural producers has always been to provide the quantity of available nutrients need to achieve the maximum economic yield for crops. As genetic yield potential for corn increases, so will the demand for nutrients. Wise use of limited, unrenewable nutrient imputes becomes increasingly important. This research with new polymer technology shows that modification of the micro-environment around the fertilizer $\mathrm{P}$ granule can improve efficiency of nutrients resulting in increased yield of crops. This technology has the potential to improve crop yields, increase producer profits and also to have positive implications on the environmental footprint of fertilizer use. More research is needed to determine the effect of $\mathrm{P}$ with Avail on crops under limited irrigation and dryland conditions and $\mathrm{P}$ content in the soil to improve application recommendations.

\section{ACKNOWLEDGEMENT}

Researcher greatly appreciate financial support from Specialty Fertilizer Products (SFP) for conducting field research.

\section{REFERENCES}

Ching, P.C. and S.A. Barber, 1979. Evaluation of temperature effects on K uptake by corn. Agron. J., 71: 1040-1044. DOI: 10.2134/agronj1979.00021962007100060035x

Cooke, G.W., 1981. The Fate of Fertilizers. In: The Chemistry of Soil Processes, Greenland, D.J. and M.H.B. Hayes (Eds.)., John Wiley and Sons, London, ISBN-10: 0471276936, pp: 563-592.
Cordell, D., J.O. Drangert and S. White, 2009. The story of phosphorus: Global food security and food for thought. Global Env. Change, 19: 292-305. DOI: 10.1016/j.gloenvcha.2008.10.009

Gerke, J., 1992. Orthophosphate and organic phosphate in the soil solution of four sandy soils in relation to $\mathrm{pH}$-evidence for humic-FE-(AL-) phosphate complexes. Commun. Soil Sci. Plant Anal., 23: 601612. DOI: 10.1080/00103629209368612

Gerke, J., 1993. Phosphate adsorption by humic/Fe-oxide mixtures aged at $\mathrm{pH} 4$ and 7 and by poorly ordered Fe-oxide. Geoderma, 59: 279-288. DOI: 10.1016/0016-7061(93)90074-U

Gilbert, N., 2009. The disappearing nutrient. Nature, 461: 716-718. DOI: 10.1038/461716a

Havlin, J.L., J.D. Beaton, S.L. Tisdale and W.L. Nelson, 2005. Soil Fertility and Fertilizers: An Introduction to Nutrient Management. 7th Edn, Prentice Hall, Upper Saddle River, NJ., ISBN-10: 0130278246, pp: 515.

Mackay, A.D. and S.A. Barber, 1984. Soil temperature effects on root growth and phosphorus uptake by corn. Soil Sci. Soc. Am. J., 48: 818-823. DOI: 10.2136/sssaj1984.03615995004800040024x

Murphy, L. and L. Sanders, 2007. Improving N and P use efficiency with polymer technology. Proceedings of the Indiana Certified Crop Advisors Conference (CD-AY-330) Tony Vyn Indianapolis, Dec. 18-19, India, pp: 1-13.

Widdowson, F.V. and A. Penny, 1973. Yields and N.P, $\mathrm{K}$ contents of crops grown in the Rothamsted Reference Experiment, 1956-1970. Rothamsted Exp. Stn. for 1972, Rothamsted, UK. 